Open Access to Pharmaceutical and Medical Research

(C) 2011-18, publisher and licensee JDDT, This is an Open Access article which permits unrestricted non-commercial use, provided the original work is properly cited

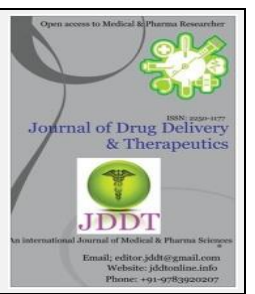

Open $\odot$ Access

Review Article

\title{
Therapeutic Potential of Widely Used Unani Drug Asl-Us-Soos (Glycyrrhiza glabra Linn.): A Systematic Review
}

\author{
* Ishtiyaq Ahmad 1, Alam Abrar 1, Siddiqui Javed Inam 2, Kazmi Munawwar Husain 3 \\ ${ }^{1}$ P.G Scholar, Ilmul Advia (Unani Pharmacology), Central Research Institute of Unani Medicine, Hyderabad, India \\ ${ }^{2}$ Lecturer, Ilmul Advia (Unani Pharmacology), Central Research Institute of Unani Medicine, Hyderabad, India \\ ${ }^{3}$ Professor \& HoD, Ilmul Advia (Unani Pharmacology), Central Research Institute of Unani Medicine, Hyderabad, India
}

\begin{abstract}
Plants have been one of the important sources of therapeutics or other human health benefits since the beginning of human civilization throughout history. Currently, there is increasing awareness and general acceptability of the use of herbs, as a medicines, health products, pharmaceuticals, food supplements, cosmetics etc. Traditional system of medicine including Ayurveda, Unani, and Siddha etc. contributed in Health care dealing worldwide. The Unani system of medicine (USM) is an age old system of medicine which has a holistic approach to treat various kind of disease; most of the time the drugs mentioned in this system has tremendous effects in chronic disease.

Asl-Us-Soos (Glycyrrhiza glabra Linn), is a widely used herb in USM. Although the review articles on this plant are already published, this review article is presented to comply all the updated information on its therapeutic potency based on phytoconstituents and pharmacological activities and the potency which is described by renowned Unani physicians and scholars. The evidence based studies provides strengthen to the concept of Unani physicians as the Unani physician used and recommended the drug since along. Moreover the evidence based studies indicate that Glycyrrhiza glabra Linn possesses antibacterial, antioxidant, antimalarial, antispasmodic, expectorant, aphrodisiac, antimycobacterial activity, antiinflammatory and anti-hyper glycemic properties. Various other effects like antiulcer, antiviral, antihepatotoxic, antifungal and herpes simplex have also been studies. These results are very encouraging and indicate that this Unani drug can be studies more extensively with a well-planned and systematic scientific preclinical and clinical approach to explore the promising outcome. Further this review gives an account of the current knowledge on the morphological characters, microscopic characters, phytochemistry, and pharmacological actions present in root of Glycyrrhiza glabra along with its actions and therapeutic potential in the perspective of USM.
\end{abstract}

Keywords: Glycyrrhiza glabra, therapeutic potential, USM

Article Info: Received 21 June 2019; $\quad$ Review Completed 04 August 2019; $\quad$ Accepted 19 August 2019; Available online 25 August 2019

Cite this article as:

Ishtiyaq A, Alam A, Siddiqui JI , Kazmi MH, Therapeutic Potential of Widely Used Unani Drug Asl-Us-Soos (Glycyrrhiza glabra Linn.): A Systematic Review , Journal of Drug Delivery and Therapeutics. 2019; 9(4-s):765-773 http://dx.doi.org/10.22270/jddt.v9i4-s.3318

*Address for Correspondence:

Ishtiyaq Ahmad, Dept. of Ilmul Advia, Central Research Institute of Unani Medicine, AG Colony Road Erragadda, Hyderabad, TS, 500038

\section{Introduction}

Traditional system of medicine including Ayurveda, Unani, and Siddha etc. contributed in Health care dealing worldwide. The Unani system of medicine is an age old system of medicine which has a holistic approach to treat various kind of disease; most of the time the drugs mentioned in this system has tremendous effects in chronic disease. In Unani medicine there are three sources of drugs e.g. plant, mineral, and animal. Majority of drugs obtained from plants and their products. These crude drugs have different medicinal values.

Glycyrrhiza glabra Linn. is a perennial plant of the family Fabaceae and is well known as Asl-Us-Soos (licorice) in Unani system of medicine. G. glabra is an oldest medicinal plant and used in various traditional system of medicine for its medicinal values, it is widely distributed in subtropical and warm regions.

Asl-us-Soos is a type of hardy herb or undershrub. The drug is widely known as licorice or licorice roots. The licorice roots are thick, having many branches with red or lemon colour in outside, and yellowish or pale yellow in inside, wrinkled fibrous wood, which has sweet taste due to glycyrrhizin, which is 50 time sweet than sugar. ${ }^{1,2}$

On large scale the Asl-us-Soos is found in spin, England, Sicily, Iran, Iraq, and Russia etc., in India it is cultivated in Punjab, Jammu and Kashmir and Andaman Island etc. ${ }^{3,11}$ 
In Unani system of medicine the Asl-us-soos has been frequently used from centuries in the treatment of $S u^{\prime} \bar{a} l$ (cough), Dìq al-Nafas(bronchial asthma) , rabw (bronchial asthma),Hurqa al-Bawl(Burning micturition), sozāk (gonorrhea) Qurūḥ al-Mathāna, Jara al- Mathāna, Buḥha alSawt (hoarseness) , Qurūh-i-Huzūmi (peptic ulcer),Nār farsi (eczema) etc. 3,4

Even today Asl-us-Soos is widely used for antimicrobial antioxidant, anticoagulative, antiallergic, expectorant, antiulcer, anxiolytic properties and for various pharma logical actions. ${ }^{5}$

\section{Botanical descriptions}

Asl-us-Soos consist of the dried root of Glycyrrhiza glabra Linn. family fabaceae.

Achieved a height of 1.8 meter. Leaves impariprinnate; leaflets in 4-7 pair, ovate-lenceolate, smooth. Flowers born in axillary spikes, papilionaceous, lavender to violet in colour. Pads compresses. Seed2-3, flat deep grey. The plant is cultivated by planting rhizome or stonlon cutting in well moist sandy soil in march. 1,6

Vernacular name $3,4,6,8,9$

Hindi:

Mulethi, Mulathi, Mulhatti, Jathimadh

English

Liquorice, licorice

Unani

Asl-us-soos, Mulethi

Arabic

Asl-us-soos

Persian

Beekh-e-Mahak

Ayurvedic

Yashtimadhu, Madhuli, Madhuka, Yashti,

Yastikaahva

Malayalam Irati-madhuran

Sanskrit Madhuyashti

Assam Jesthimadhu

Bengal Jashtimadhu

Gujarat Jethimadhu

Orissa Jatimadhu. Jastimadhu

Tamil Athimadhuram,

Telgu Atimadhuram

\section{Organoleptic Characters of Root of Asl-us-Soos ${ }^{11}$}

Colour Red or lemon colour in outside, yellowish or pale yellow in inside

Odour Faint and characteristic

Taste Sweet

Size Length $20-50 \mathrm{~cm}$, diameter $2 \mathrm{~cm}$

Shape Cylindrical pieces

Fracture It is fibrous in the bark and splinter in wood

\section{Microscopic Characters of Root of Asl-Us-Soos}

Histological diagnostic characters of Asl-us-Soos are unpeeled drugs the presence of polyhedral tubular brownish cork cells. Fibers are thick, lignified or partially lignified, in the group of 10-15 in phloem and xylem. Vessels are large and closely arranged with bordered pits. Starch and calcium oxalate crystals are present in parenchyma. In the stolon, the pith is present and is parenchymatous, and in case of roots the presence of tetrarc xylem and absent of pith. ${ }^{11}$

\section{Chemical constituents}

The Asl-us-Soos (licorice root) is contains various types of chemical constituent mainly Flavonoids, sugar, amino acid, starch, resins, sterols and essential oil.

Asl-us-Soos is mainly composed of triterpenes saponin 4$20 \%$ included; glycyrrhizin or glycyrrhizic acid and licorice root also contained other triterpenes like liquiritic acid, glycyrretol, glabrolide, isoglaborlide and liquirce acid.

Flavonoids and chalcones isolated from Asl-us-Soos are liquiritin, liquiritigenin, hamnoliquiritin, neoliquiritin, chelcones isoliquiritin, isoliquiritigenin, neoisoliquiritin, licuraside, glabrolide, licoflavonol, 5,8-dihydroxy-flavone-7O-beeta-D-glucuronide etc.

Other constituents of Asl-us-soos (licorice root) are glucose upto $4 \%$, sucrose $2.5-6.5 \%$, resins, essential oil, sterols, steroids, amino acid, starches, pectin, mucilage, lipid, and tenninetc. $6,8,9,11,12,13$

The Asl-us-Soos (licorice root) also contain few heavy metal like; Cd (Cadmium), Pb (lead), Ar (Arsenic), Hg (Mercury) and the trace elements are also present in the root powder of licorice were; Potassium:0.66\%, Calcium:1.87\%, Sulphur: 0.06\%, Iron:0.14\%, Aluminium: 0.05\%, Phosphorous: 0.06\%, Silicon: $0.12 \%$, Magnesium: $0.17 \%$, Sodium: $0.04 \% .{ }^{14}$ 
Table 1: List of Few Chemical Constituents Responsible for the Bioactivity ${ }^{71}$

\begin{tabular}{|c|c|c|c|}
\hline S.no & Name of Chemical Constituent & Class of Chemical Constituent & Biological Activity \\
\hline 1. & Glabridin, glabrene, glycyrrhizinic acid & $\begin{array}{l}\text { Flavonoid, isoflavan, saponin } \\
\text { glycoside }\end{array}$ & Antiulcer activity \\
\hline 2. & Glabridin & Flavonoid & Antimycobacterial activity \\
\hline 3. & Isoliquiritigenin & Flavonoid & $\begin{array}{l}\text { Analgesic \& uterine } \\
\text { Relaxant activity }\end{array}$ \\
\hline 4. & $\begin{array}{l}\text { Licochalcone, glabridin, isoliquiritigenin, } \\
\text { licocoumarin }\end{array}$ & Chalcone, flavonoid & Antioxidant activity \\
\hline 5. & Glabridin & Flavonoid & Memory enhancer activity \\
\hline 6. & 18 - $\beta$-glycyrrhetinic acid & Triterpenoid saponin glycoside & Corticosteroid like activity \\
\hline 7. & $\begin{array}{c}\text { Glycyrrhizin, } 18-\beta \text {-glycyrrhetinic acid, } \\
\text { liquiritigenin }\end{array}$ & $\begin{array}{l}\text { Triterpenoid saponin glycoside, } \\
\text { flavanone }\end{array}$ & Antiallergic activity \\
\hline 8. & Glycyrrhizin & Triterpenoid saponin glycoside & Hepatoprotective activity \\
\hline 9. & $\begin{array}{l}\text { Glycyrrhetic acid, liquiritoside, } \\
\text { Licochalcone a }\end{array}$ & Chalcone & Anti-inflammatory activity \\
\hline 10. & Glycyrrhetic acid, Glycyrrhizin & Triterpenoid saponin glycoside & Anticancer activity \\
\hline 11. & Licochalcone A & Chalcone & Antimalarial activity \\
\hline 12. & $\begin{array}{l}\text { Glycyrrhizin, licochalcones, glycyrrhetinic } \\
\text { acid }\end{array}$ & Triterpenoid saponin glycoside & Antiviral activity \\
\hline 13. & 18 - $\beta$-glycyrrhetinic acid, glycyrrhizin & Triterpenoid saponin glycoside & Antihyperglycemic activity \\
\hline 14. & Glycyrrhizin & Triterpenoid saponin glycoside & $\begin{array}{c}\text { Anticancer activity } \\
\text { hepatocellular carcinoma }\end{array}$ \\
\hline 15. & Glycyrrhizin & Triterpenoid saponin glycoside & Antitussive activity \\
\hline 16. & Glycyrrhizin, isoliquiritigenin & $\begin{array}{l}\text { Triterpenoid saponin glycoside, } \\
\text { flavonoid }\end{array}$ & Antithrombin activity \\
\hline 17. & Glycyrrhetinic acid & Triterpenoid & $\begin{array}{l}\text { Immunostimulating } \\
\text { activity }\end{array}$ \\
\hline 18. & Glycyrrhizin & Triterpenoid saponin glycoside & Anti HIV \\
\hline 19. & Glycyrrhizin & Triterpenoid saponin glycoside & $\begin{array}{l}\text { Hepato protective activity } \\
\text { inChronic hepatitis C }\end{array}$ \\
\hline 20. & Liquiritin & Flavonoid & Spasmolytic activity \\
\hline 21. & Rhamnoglucoside & Flavanone & Muscle relaxant \\
\hline 23. & Glabrene, liquiritigenin & Isoflavan, flavanone & Estrogenic activity \\
\hline
\end{tabular}

Mizāj (temperament) ${ }^{3,10,15,16,17}$

$\boldsymbol{H a ̄ r}$ (Hot) 20, Yābis (Dry) $1^{\circ}$

Muḍir(Contraindication): for kidney, and spleen 4,17,18

Muṣliḥ (Correctives): 4,17,18

kateera is recommended in kidney diseases

Gul-i-Surkh is recommended in spleen diseases

Badal (substitute): kateera is recommended in chest pain $4,17,18$

Doses : 3 -7 gm 4,8,9,17,18,19

Doses forms: The drug can be used alone in Safüf (powder) form, Joshanda (decoction), or may be used along with other ingredients. $3,15,17$

\section{Af'āl (Action):}

Muqawwī-i-A'sāb (nervine tonic), musakkin (analgesic), Mulayyin (laxative), Muhallil (resolvent), Munaffith-iBalgham wa Mukhrij-i-Balgham (expectorant), Jāli (detergent), Muqawwi(tonic), Kāsir-i-Riyāh (carminative), mudirr-i-Bawl (diuretic), mudirr-i-Hayd (emmenogogue), Su'āl (cough), Muqawwi-i-Bāh, Dāfi'-i-Khushūna al-Halaq, Dāfi'-i-Humūzat-i-mi'da, Muqi, Mugharrī, Dāfi'-i-Tip hā-iMuzminā, Ghāsil-i-āzā-i-Bātina, Musakkin-i-Tishnagi. $3,4,8,10,12,17,19$

\section{Iste'māl (Therapeutic uses)}

In Unani system of medicine, the Asl-us-Soos used in Qurūh-iHuzūmi (peptic ulcer), Waj'ul-Mafasil (arthritis), Amrāz-iKabid (liver diseases), Su'āl (cough), Dìq al-Nafas(bronchial asthma), Rabw (bronchial asthma), Hurqa al-Bawl(Burning micturition), sozāk (gonorrhea) Qurūh al-Mathāna, Jara alMathāna, Buḥha al-Sawt (hoarseness), Bayad al-'ayn (corneal opacity),

In traditional system of medicine Asl-us-Soos is recommended for the treatment of epilepsy. It is used in sex hormone imbalance condition, and also used in early menopausal condition in women. Asl-us-Soos content flavonoids-Isoliquiritin with antigastric effect so used in peptic ulcer in form of deglycyrrhized liquorice, in the presence of glycyrrhitinic acid it is employed in place of corticosteroids for the treatment of rheumatoid artharitis, inflammation and addision's disease, glycyrrhizinic acid is also used for the common cold, viral hepatitis, viral infaction, externally it is applied with honey for treatment of Dākhis (paronychia), honey and ghee for cuts and wounds. Topically, Asl-us-Soos powder used in Namla (Herpes), nār farsi (eczema) and Dā'ssadaf (psoriasis). Asl-us-soos in bulk amount increase fluid and sodium retention and promoted potassium depletion, therefore it should be used carefully in patient with cardiac problem and hypotension etc. $13,4,6,7,8,9,10,12,15,16,17,18,19$ 


\section{Mashhūr Murakkabāt (Important formulation)}

The drug Asl-us-Soos used along with other ingredient in the following Unani formulation, Sufüf-i- asl-us-soos, Habb-ebanafshā, Habb-e-ghāriqoon, Habb-e-surfa, Habb-e-surfā qawi, Qurs-e-zarishk, Sharbat-e-aijaz, Sharbat-e-Sadar, Dayaqooza, Lauq-e-Hulba, Lauq-e-Amaltas, Lauq-e-Khiyar shambar, Lauq-e-Nazli, Lauq-e-Sapistan, Lauq-e-Shamoon, Lauq-e-Zeequn Nafas, Jwarish-e- asl us soos, Majoon Mundi, Qairooti-e-Aard-e-karsana, Raughan-e-Sanan. 3,4,8,17

\section{Evidence based scientific studies}

\section{Activity on memory and learning}

In an experimental study on three month old male rat, the aqueous extract of Glycyrrhiza glabra root (75, 150 and 300 $\mathrm{mg} / \mathrm{kg}$ for 2 weeks) showed learning and memory enhancement activity. Elevated plus-maze and Morris water maze tests were conducted to evaluate the learning and memory parameters as exteroceptive behavioral model and Diazepam induced amnesia as interoceptive behavioral model. The aqueous extract of root of Glycyrrhiza glabra showed improvement in learning and memory in a dose dependent manner. ${ }^{20,21}$

In an experimental study the effects of aqueous extract of Glycyrrhiza glabra root extract $(75,150,225$, and 300 $\mathrm{mg} / \mathrm{kg}$, for six successive weeks) on learning and memory were studied in 1-month-old male Wistar albino rats using the elevated plus maze, Hebb-William maze, and Morris water maze tests as exteroceptive behavioral model and Diazepam-induced amnesia as interoceptive behavioral model. Results revealed that all the doses of aqueous root extract of Glycyrrhiza glabra significantly enhanced the memory, the doses 150 and $225 \mathrm{mg} / \mathrm{kg}$, possessed significant $(\mathrm{P}<0.01)$ enhancement in learning and memory. Furthermore, diazepam-induced amnesia was reversed by the aqueous root extract of Glycyrrhiza glabra (150 and 225 $\mathrm{mg} / \mathrm{kg}, \mathrm{po}) .22$

In a study, the cognitive functions and cholinesterase activity ware investigated in mice. glabridin isolated from the roots of Glycyrrhiza glabra. Glabridin (1, 2 and $4 \mathrm{mg} / \mathrm{kg}$, po) was administered daily for 3 successive days to mice. The higher doses (2 and $4 \mathrm{mg} / \mathrm{kg}$ po) of glabridin significantly antagonized the amnesia induced by scopolamine 0.5 $\mathrm{mg} / \mathrm{kg}$ ip) in both the elevated plus maze test and passive avoidance test Glabridin ( 2 and $4 \mathrm{mg} / \mathrm{kg}$ po) also remarkably reduced the brain cholinesterase activity in mice compared to the control group. 23

In a clinical study, The effect of Glycyrrhiza glabra oral supplementation was evaluated on the mental intelligence and memory function of the male students. Glycyrrhiza glabra tablets were formulated from the crude powder prepared from roots and subjected to dose standardization process. 123 students were divided into two group,treatment (1 tablet two times/ day) and placebo control (received starch powder) for the period of 60 days. Each group was further subdivided into two, based on low and high intelligence percentage in order to avoid biasness.Evaluation of improvement was judge by using NVIT (Non Verbal Intelligence Test) and memory test score before the start and at the end of treatment period and scored them accordingly into poor, moderate, good and,very good and expressed in percentage. The overall NVIT results indicated that oral consumption of Glycyrrhiza glabra tablets twice a day improved the intelligence level among the student compared to placebo treatment. ${ }^{24}$

The natural product 2,2',4'-trihydroxychalcone (TDC) obtained from Glycyrrhiza glabra was evaluated for its activity in a Alzheimer diseases mice model. $9 \mathrm{mg} / \mathrm{kg} /$ day of TDC decreased $A ß$ production and $A ß$ plaque formation, and efficiently improve the memory impairment based on Morris water maze test. 25

\section{Activity on Respiratory System}

In a clinical studied, the Glycyrrhiza glabra showed the bronchorelaxant effect. A clinical trail (54 patients) in comparison with Boswellia carterii (Olibanum) and prednisolone (18 patients each group) for 21 days.Pulmonary function tests and serum electrolytes: calcium, magnesium, potassium and selenium were done before and after the study. The results showed that the tested plants had significant elevation in the values of forced expiratory volume in first second (FEV1\%) as $(72.45 \pm 5.83$ vs $61.33 \pm 6.04$ and $81.10 \pm 11.07$ vs $62.30 \pm 7.22$ ) for olibanum and licorice respectively. Also, elevation in the values of forced volume capacity(FVC) with marked reduction in asthmatic attacks as $(2.63 \pm 0.82$ vs $0.72 \pm 0.16,3.60 \pm 0.02$ vs $1.08 \pm 0.08$, and $2.25 \pm 0.16$ vs $1.05 \pm 0.15$ ) for olibanum, licorice and prednisolone respectively, with better symptomatic improvement in licorice group as compared to olibanum. Glycyrrhiza glabra was significantly elevated Mg: from $0.66 \pm 0.17$ to $1.02 \pm 0.10$, Se: from $28.19 \pm 3.72$ to $51.70 \pm 8.63$, Ca: from $1.90 \pm 0.062$ to $.30 \pm 0.08$ and $\mathrm{K}$ : from $3.60 \pm 0.03$ to $4.10 \pm 0.12 .26$

In another clinical study, Glycyrrhiza decreased irritations in the throat and produced expectorant effects. It was assumed that Glycyrrhiza was able to stimulate tracheal mucus secretions and produce demulcent and expectorant effects. $26,27,28$

Its powder and extract was useful for the treatment of sore throat, cough and bronchial catarrh. It also possessed antitussive and expectorant. ${ }^{29}$

\section{Antidepressant activity}

In an experiment, the aqueous extract of root of Glycyrrhiza glabra showed anti-depressant effects in mice by using forced swim test (FST) and tail suspension test (TST). The extract of Glycyrrhiza glabra $(75,150$, and $300 \mathrm{mg} / \mathrm{kg})$ was administered orally for 7 successive days in separate groups of male mice. The dose of $150 \mathrm{mg} / \mathrm{kg}$ of the extract significantly reduced the immobility times of mice in both FST and TST, without any significant effect on locomotor activity of mice. The efficacy of extract was found to be comparable to that of imipramine $(15 \mathrm{mg} / \mathrm{kg}$ ip $)$ and fluoxetine $(20 \mathrm{mg} / \mathrm{kg}$ ip). Liquorice extract reversed reserpine-induced extension of immobility period of mice in FST and TST. Sulpiride $(50 \mathrm{mg} / \mathrm{kg}$ ip, a selective D2 receptor antagonist) and prazosin $(62.5 \mu \mathrm{g} / \mathrm{kg}$ ip, an a1-adrenoceptor antagonist) significantly attenuated the extract-induced antidepressant-like effect in TST. On the other hand, $p$ chlorophenylalanine $(100 \mathrm{mg} / \mathrm{kg}$ ip, an inhibitor of serotonin synthesis) did not reverse antidepressant-like effect of liquorice extract. It seemed that the antidepressantlike effect of liquorice extract mediated by increase of brain norepinephrine and dopamine, but not by increase of serotonin. ${ }^{30}$

\section{Anti-inflammatory activity}

In an experimental study, the anti-inflammatory activity of hydro alcoholic extract of Glycyrrhiza glabra (HAEGG) root was evaluated against carrageenan induced rat paw oedema at dose levels of 100,200 , and $300 \mathrm{mg} / \mathrm{kg}$ orally. The hydro alcoholic extract of Glycyrrhiza glabra showed a maximum (46.86\%) inhibitory action on carrageenan induced paw oedema at the dose of $200 \mathrm{mg} / \mathrm{kg}$ and inhibited the leukocyte migration in a dose dependent manner. ${ }^{31}$ 
In another activity, the anti-inflammatory activity was comparable to indomethacin $(10 \mathrm{mg} / \mathrm{kg})$ Several secondary metabolites isolated from rhizomes of Glycyrrhiza glabra were investigated for the ${ }^{30}$ COX-2 inhibitory activity using Cayman COX (ovine) inhibitory screening assay. A few molecules showed potent COX-2 inhibitory activity which may beneficial as anti-inflammatory agents. ${ }^{31}$ Glycyrrhizin exhibited steroid-like anti-inflammatory activity, similar to hydrocortisone due to inhibition of phospholipase A2 activity, glycyrrhizic acid inhibited cyclooxygenase activity and prostaglandin formation (specifically prostaglandin E2), as well as indirectly inhibiting platelet aggregation. $32,33,34$

\section{Antimicrobial activity}

The antibacterial effect of alcoholic extract obtained by percolation from roots of Glycyrrhiza glabra was tested against Escherichia coli, Pseudomonas fluorescens, Enterococcus faecalis, Bacillus cereus, and Staphylococcus aureus, the extract showed the strong antibacterial activity against all bacterial strains tested.The maximum inhibition diameter was $15 \mathrm{~mm}$ against E. coli, E. faecalis, B.cereus, whereas $P$. fluorescensshowed the lowest sensitivity, with an inhibition zone of $9 \mathrm{~mm} .35$

The antimicrobial effect of the methanolic extract of Glycyrrhiza glabra was investigated against B. megaterium, B. subtilis, Staphylococcus aureus, Sarcina lutea, Escherichia coli, Pseudomonas aeruginosa,Salmonella paratyphi, S. typhi, Shigella boydii, $S$. dysenteriae, Vibrio mimicus and $V$. parahemolyticus. The Glycyrrhiza glabra methanolic extract showed potent antimicrobial activity against almost all the tested organisms except Pseudomonas aeruginosa. It exhibited highest activity against Staphylococcus aureus with a zone of inhibition of $22 \mathrm{~mm} .{ }^{36}$

The ethanolic extract of Glycyrrhiza glabra root was showed antimicrobial activity at $500 \mathrm{~g} / \mathrm{mL}$ against Mycobacterium tuberculosis H37Ra and H37Rv strains through BACTEC assay. The MIC of test compounds was noted on the basis of GI (growth index) value. Further, the ethyl acetate fraction showed better activity at a concentration range of 100-250 $\mathrm{g} / \mathrm{mL}$.The column fraction eluted with chloroform: ethyl acetate (96:4) was found to be still more active against tubercular bacilli at $50-120 \mathrm{~g} / \mathrm{mL}$. The antitubercular activity of glabridin was found to be at $29.16 \mathrm{~g} / \mathrm{mL}$ against both the strains of Mycobacterium. Additionally, glabridin was more active against Gram-positive strains than Gramnegative. ${ }^{37}$

The antimicrobial activity of methanolic extract and different fractions ( $n$-butanol, ethyl acetate, chloroform and $n$-hexane) of Glycyrrhiza glabra root was studied against four bacterial strains Escherichia coli, Bacillus subtilis, Staphylococcus aureus and Pasturella multocida and three pathogenic fungi, Aspergillus niger, Aspergillus flavus and Rhizopus solani using disc diffusion and minimum inhibitory concentration methods. As general, plant extract and fractions were mildly potent antimicrobial agent. The results indicated that $100 \%$ methanolic extract showed good activity against $E$. coli and B. subtilis, showing the highest inhibition zones ( 33 and $27.5 \mathrm{~mm}$ ) and the lowest MIC values $(9.28$ and $30.2 \mathrm{mg} / \mathrm{ml}$ ), respectively. Least activity was exhibited against $\mathrm{A}$. niger and $R$. solani with the smallest inhibition zones $(16.5$ and $16 \mathrm{~mm})$ and the highest MIC values (150 and $152 \mathrm{mg} / \mathrm{ml}$ ). 80\% methanolic extract showed strong activity against $B$. subtilis and $E$. coli with inhibition zones ( 30 and $28.5 \mathrm{~mm}$ ) and the lowest MIC values $(12.2$ and $20.1 \mathrm{mg} / \mathrm{ml})$, respectively. Least activity was exihibited against $S$. aureus with inhibition zone (19 $\mathrm{mm})$ and the highest MIC value $(110 \mathrm{mg} / \mathrm{ml})$, respectively.
$80 \%$ methanolic fraction showed magnificent activity against $A$. niger as compared to standard drug fluconazole. ${ }^{38}$

There are many studies have demonstrated that glycyrrhizin of licorice was responsible for the antiviral activity.The possible antiviral mechanisms of these compounds were (HCV): affected release step while infectious HCV particles are infecting cells. Inhibited HCV full length viral particles and HCV core gene expression. (HSV): reduced adhesion force and stress between CCEC and PMN. (CVB3): blocked the degradation of nuclear factor $\kappa \mathrm{B}$ inhibitor $\mathrm{I} \kappa \mathrm{B}$. (DHV): activated $\mathrm{T}$ lymphocyte proliferation. (H5N1): weakened H5N1-induced production of CXCL10, IL-6 and CCL5, and suppressed H5N1-induced apoptosis. (Influenza virus): reduced HMGB 1 binding to DNA, and inhibited influenza virus polymerase activity. ( CVA16 EV71): inactivated CVA16 directly, while the effect of anti-EV71 was associated with an events during the virus cell entry. (HSV1): established a resistance state to HSV1 replication. (Rotavirus): reduced the levels of viral proteins VP2, VP6 and NSP2 at a step or steps subsequent to virus entry. 39

\section{Anticancer activity}

The antitumor activity of methanolic extract of licorice $(0$, $12.5,25,50$ and $100 \mu \mathrm{g} / \mathrm{ml}$ ) was evaluated against intestinal carcinoma cell line (Caco-2) and prostate carcinoma cell line (PC-3). Licorice methanolic extract had a growth inhibitory action against Caco-2 and PC-3 with IC50 values of 40 and $40.6 \mu \mathrm{g} / \mathrm{ml}$, respectively. 40

In an experimental study, the methanolic extract of Glycyrrhiza showed anticancer activity by using brine shrimp lethality bioassay methods. The extract possessed potent cytotoxic activity with LC 50 value of $0.771 \mu \mathrm{g} / \mathrm{ml} .{ }^{36}$

Isoliquiritigenin(ISL) is one of the natural bioactive ingredient isolated from the root of Glycyrrhiza glabra prevented the incidence of 1,2- dimethylhydrazine-induced colon and lung tumors in mice when administered at a dose of $300 \mathrm{mg} / \mathrm{kg}$. 41

In another study, Isoliquiritigenin was considered to be nonhormonal alternatives in botanical supplements. Exposure of ISL to HeLa cells-induced apoptosis. The oxidative stresses, mitochondrion-dependent and the estrogen receptor stresstriggered signaling pathways, were considered to be the reasons of apoptosis in HeLa cells (Yuan et al., 2013b). Isoliquiritigenin treatment inhibited cell proliferation of HeLa cells with increased apoptotic rate and cancer U14 cells. ${ }^{41}$

The cytotoxic activity of different extracts of Glycyrrhiza glabra was tested on mice transformed cell line. The results showed that hot alcoholic extract possessed the greatest cytotoxic effect on the cancer cells $(\mathrm{P}<0.05)$ after 72 hourse exposure. ${ }^{42}$

The antiangiogenic and antitumor activity of Glycyrrhiza glabra were investigated on VEGF and MTA1 induced angiogenesis. The angio inhibitory activity of Glycyrrhiza glabra was confirmed by its inhibition of angiogenesis, peritoneal and chorioallantoic membrane assay. Reduction in the levels of them cytokine VEGF and microvessel density count in the peritoneum of mice treated with Glycyrrhiza glabra indicated that the plant extract decreased VEGF production. It also inhibited the neovascularization in CAM induced by VEGF and MTA1. 43

\section{Effect in Gastro -Duodenal Ulcers}

In an experimental study, Carbenoxolone a glycyrrhetinic acid derivative with a steroid like structure, found in root of liquorice plant, was effective in the treatment of gastric and 
duodenal ulcer at the medium dose of $100 \mathrm{mg}$ three times a day. Liquorice can raise the concentration of prostaglandins in the digestive system that promote mucus secretion from the stomach, it was also prolonged the life span of surface cells in the stomach and has an anti-pepsin effects. $44,45,46,47,48$

In a clinical study, 40 patients treated either 3.0 or $4.5 \mathrm{~g}$ deglycyrrhizinated licorice (DGL) daily for eight weeks, were assessed for relief from epigastric pain, nausea, vomiting, $\mathrm{x}$ ray of ulcer craters to determine changes in size of ulcer, and frequency of relapse. All patients showed significant improvement after 5-7 days. ${ }^{49}$

In another clinical study, more larger trial carried out on 874 patients with chronic duodenal ulcers. Patients were received DGL (deglycyrrhizinated licorice), cimetidine, or antacids. No differences were recorded among groups in the rate of ulcer healing, but patients in the DGL group showed less occurance of relapses. ${ }^{50}$

The anti- Helicobacter pylori activity of glycyrrhizic acid, glycyrrhetinic acid and a novel lipophilic derivative of glycyrrhetinic acid monoglucuronide acetylated (GAMG) was tested against 29 Helicobacter pyloristrains. Glycyrrhetinic acid was the most potent compound (MIC 50 /90, 50/100 mg/l), inhibiting $79.3 \%$ of the strains at MIC $<50 \mathrm{mg} / \mathrm{l} .{ }^{51}$

\section{Activity on smooth muscles}

In an experimental study, the effect of hydro-alcoholic extract of licorice rhizome is studied on mechanical activity of isolated colon in male rats. The mechanical activity of tissue in presence of extract and epinephrine was significantly decreased $(p=0.05)$ compared to the control group. While the mechanical activity in the presence of extract and propranolol was significantly increased $(p=0.05)$ compared to the control group. However, no significant modification was observed in the mechanical activity of the tissue in the presence of phenylephrineand extract compared to the control group. According to the result, it appeared that hydro-alcoholic extract of licorice had modifying effect on colon motility via synergist effect with beta adrenergic receptors and independent of the alpha adrenergic receptors. ${ }^{52,53}$

Isoliquiritigenin isolated from an aqueous extract of licorice root was a potent relaxant, it inhibited the contraction induced by various types of stimulants, such as $\mathrm{CCh}, \mathrm{KCl}$, and $\mathrm{BaCl} 2$ with IC50 values of $4.96 \pm 1.97 \mathrm{microM}, 4.03 \pm 1.34$ microM and 3.70 \pm 0.58 microM.54,55

In an in vitro study, the mechanisms of action of licorice rhizome extract on duodenal motility were investigated in rats. Mechanical activity in response to extract $43 \mu \mathrm{g} / \mathrm{ml}$ (most effective concentration based on concentration/response experiments) in the presence of acetylcholine (10-5 M) as the muscarinic receptoagonist, atropine (10-4 M) as the muscarinic receptor antagonist, epinephrine (10-6 M) as the $ß$-adrenoceptoagonist, propranolol as $ß$ receptor antagonist, or $\mathrm{N}$ - $\mathrm{W}$ - nitro- $\mathrm{L}$ arginine methyl ester (L-NAME) (10-4 M) as the inhibitor of the NO synthase enzyme was measured. The results showed that the contraction force exerted on the isolated duodenum pieces by acetylcholine was remarkably reduced in the presence of licorice rhizome extract compared to that of the control group $(\mathrm{P}<0.05)$. However, this response in the presence of atropine,propranolol and (L-NAME) was not changed significantly. According to the results of the study, alcoholicextract of licorice rhizome decreases bowel motility. This inhibitory effect was independent of cholinergic, $ß$-adrenergic and nitrergic pathways. ${ }^{56}$

\section{Anti-diabetes activity}

In this experimental study, the anti-diabetic effects of glycyrrhizin were investigated by using genetically noninsulin dependent diabetic Mellitus (NIDDM) model mice (KK-Ay), through a long-term feeding of glycyrrhizin treatment $(2.7,4.1 \mathrm{~g} / \mathrm{kg}$ diet $)$ on diabetic symptom. The rise of blood glucose concentration was almost prevent in mice fed the $0.41 \%$ glycyrrhizin diet 9 weeks after the beginning of test feeding, although it was not suppressed in mice fed the control diet or the $0.27 \%$ glycyrrhizin diet. Water intake in the control and $0.27 \%$ glycyrrhizin diet groups increased gradually, whereas, this was not true in the $0.41 \%$ glycyrrhizin diet group. Glycyrrhizin treatment significantly lowered blood insulin level. It did not affect the food intake or body weight among the groups. $0.41 \%$ glycyrrhizin diet in mice also improved their tolerance to oral glucose loading 9 weeks after the beginning of test feeding. ${ }^{57}$

In another study, the effect of glycyrrhizin on streptozotocin (STZ)-induced diabetic changes and associated oxidative stress, including haemoglobin-induced free iron-mediated oxidative reactions on Male Wistar rats.Glycyrrhizin treatment improved significantly the diabetogenic effects of STZ, it modulated blood glucose level, glucose intolerant behaviour, decreased serum insulin level including pancreatic islet cell numbers, increased glycohaemoglobin level and enhanced levels of cholesterol and triglyceride. The treatment significantly reduced diabetes-induced abnormalities of pancreas and kidney tissues. Oxidative stress parameters, serum superoxide dismutase, catalase, malondialdehyde and fructosamine in diabetic rats were reverted to respective normal values after glycyrrhizin administration. Free iron in haemoglobin, iron-mediated free radical reactions and carbonyl formation in haemoglobin were pronounced in diabetes, and were counteracted by glycyrrhizin. Effects of glycyrrhizin and glibenclamide treatments appeared comparable. 58

\section{Anti-Dyslipidemic activity}

In an experiment, the ethanolic (95\%) extract of root of Glycyrrhiza glabra and its fractions were showed its antidyslipidaemic activity on high fructose diet (HFD) induced dyslipidaemic Syrian hamsters.Ethanolic extract and its ethyl acetate soluble, water soluble and hexane soluble fractions decreased serum level of total cholesterol by $25.9,38.0,39.0$ and $26.3 \%$, respectively in high fructose diet induced dsyslipidaemic in Syrian golden hamsters. Furthermore, they also increased the serum HDL-cholesterol level by 14.8, 34.3, 27.3 and $17.2 \%$, and decreased triglyceride level by $31.3,37.2,41.2$ and $28.9 \%$, respectively. Thereduction in LDL-cholesterol level by ethanolic extract, ethyl acetate soluble fraction and water soluble fraction were $43.9,31.0,33.4$ and $24.6 \%$ respectively. ${ }^{59}$

\section{Effect on Metabolic Syndroms}

Therapeutic potential of Glycyrrhiza glabra root extract incorporated diet at $300 \mathrm{mg} / \mathrm{kg} /$ day was evaluated in a rat model with high-fat diet-induced signs of metabolic syndrome. Glycyrrhiza glabra root extract significantly reduced the weight of epididymal tissue $(19.0 \%, \mathrm{p}<0.01)$ and basal serum glucose level $(19.4 \%, \mathrm{p}<0.05)$, decreased systolic blood pressure by $12.0 \%(\mathrm{p}<0.05)$, reduced serum IL6 and corticosterone levels induced by HFD and reduced triacylglycerol accumulation in the liver.60

\section{Aphrodisiac activity}

In the experimental study, the effect of aqueous extract of Glycyrrhiza glabra roots and rhizomes showed aphrodisiac activity in male wistar rats. $150 \mathrm{mg} / \mathrm{kg} \& 300 \mathrm{mg} / \mathrm{kg} /$ day 
were administered orally by gavage for 28 days. Mount latency, intromission latency, mounting frequency, intromission frequency observed before and during the study at day $0,7,10,14,21$, and 28 . The extract reduced significantly mount latency and intromission latency. The extract also increased significantly mounting frequency and intromission frequency. 61

\section{Corticosteroid activity}

Based on the similarities in the corticosteroid hormones and the glycyrrhizate structure initial theories assumed a direct binding of $18 \beta$-glycyrrhetinic acid to the mineralocorticoid and glucocorticoid receptors in various tissues. Licorice showed mineralocorticoid properties due to the presence of glycyrrhizin and its metabolite 18ß-glycyrrhetinic acid, which was an inhibitor of cortisol metabolism. It was suggest the mineralocorticoid properties of liquorice, agonist of mineralocorticoid receptors and mild inhibitor of androgen synthesis, can reduce the prevalence of side effects related to the diuretic activity of spironolactone in patients with PCOS (Polycystic Ovarian Syndrome). ${ }^{62,63}$

Originally the structure and activity of $18 \beta$-glycyrrhetinic acid were thought to be similar to adrenal steroid hormones, such as aldosterone and cortisol, since ingestion of liquorice mimicked hyperaldosteronism and was suggested as a treatment for Addison's disease. It is now thought that the presence of intact adrenals is required for liquorice ingestion to cause sodium retention, leading to subsequent hypertension. 64

\section{Estrogenic Activity}

Glycyrrhiza glabra (25 mg alcoholic extract) showed high estrogenic activity reflected by uterine Retention response and vaginal opening. Based upon the mouse uterine weight method, three doses of $25 \mathrm{mg}$ of the alcoholic extract showed an estrogenic activity 1:4716980 of estradiol monobenzoate. 65

\section{Antioxidant effect}

Chalcone derivative, a novel group of neolignan lipid esters, and seven known phenolic compounds (formononetin, glabridin, hemileiocarpin, hispaglabridin B, isoliquiritigenin, 4'-0-methylglabridin, and paratocarpin B) isolated from the roots and stolons of Glycyrrhiza glabra were tested in an authentic peroxynitrite anti-oxidant assay. Of these compounds, hispaglabridin B, isoliquiritigenin, and paratocarpin $B$ were found to be the most potent antioxidant agents. ${ }^{41}$

In an in vitro study, the methanolic extracts of root of Glycyrrhiza glabra var. glandulifera was showed the antioxidant activity by using the DPPH (1,1-diphenyl-2picrylhydrazyl) method. The extracts showed good antioxidant activity, with a median inhibitory concentration (IC50) of $588 \pm 0.86$ to $2190 \pm 1.73 \mathrm{mg} / \mathrm{ml} .66$

In another study, the free radical scavenging of the methanolic extract of Glycyrrhiza glabra was investigated using DPPH. The extract showed moderate free radical scavenging activity with IC 50 value of $87.152 \mu \mathrm{g} / \mathrm{ml} .^{36}$

The antioxidant activity of roots extracts of Glycyrrhiza glabra was investigated with DPPH scavenging assay. The results revealed that methanolic extract of Glycyrrhiza glabra was potent antioxidant with maximum scavenging effect of $67.22 \%$ at a concentration of $500 \mu \mathrm{g} / \mathrm{ml}$. The calculated IC50 for the methanol extract of Glycyrrhiza glabra was $359.45 \mu \mathrm{g} / \mathrm{ml} .67$

\section{Immunological activity}

In an experimental study, the alcoholic extracts of root of Glycyrrhiza glabra were showed the effect on immune modulator activity. Neutrophils when treated with alcoholic extract of Glycyrrhiza glabra showed increase in phagocytic Activity. 68

The effect of Glycyrrhiza glabra root extract (0.1, 0.2 and 0.3 $\mathrm{mg} / \mathrm{l}$ drinking water) was investigated on the performance and some immunological parameters of broiler chickens. Glycyrrhiza glabra root extract had no significant $(\mathrm{P}>.05)$ effect on immunological parameters including antibody titers against Newcastle disease and Influenza viruses, heterophil and lymphocyte percentages and heterophil to lymphocyte $(\mathrm{H} / \mathrm{L})$ ratio as well as liver and lymphoid organ (bursa of Fabricius, thymus and spleen) weights. ${ }^{69}$

\section{Antiprotozoal activities}

In in vitro studies, the root of Glycyrrhiza glabra were found to be potentially inhibit the growth of Plasmodium. falciparum and Leishmania donovani, and possess antiplasmodial activity with IC50 values between 4.5 and 0.6 $\mathrm{mg} / \mathrm{mL} .70$

\section{Hepatoprotective activity}

In an in vitro study, the carbon tetrachloride-induced hepatotoxicity and retrorsine-induced liver damage, respectively, in mice and rats, glycyrrhizin and glycyrrheitinic acid were showed Hepatoprotective activity. ${ }^{70}$

\section{Central nervous system studies}

in in vitro and in vivo studies, glycyrrhizin isolated from the G.glabra has been identified as a thrombin inhibitor and showed an antiplatelet aggregation effect. G. glabra accelerated the metabolism of cells in the bone marrow erythroid stem and increased the animal's resistance to stress. 70

\section{Conclusion}

Glycyrriza glabra L. root and its extract has been used in Unani System of Medicine since a long for the treatment of various ailments like pulmonary diseases, hepatitis, gastrointestinal ulcers, skin diseases etc. It is used as common ingredient in many Unani compound formulations along with other ingredients effectively. Traditionally it is used as mild laxative, anti-arthritic, antiinflammatory, anti-ulcer, anti-tussive, aphoridisiac, antioxidant, anti-diuretic etc. The pharmacological and clinical studies reported in the present review confirm the therapeutic value of Glycyrrhiza glabra in Unani prospective also. Presence of biological active chemical constituents indicate that the drug could serve as "lead" for development of safe and effective medicinal natural products or new drugs for the benefit of mankind. In this regard, further studies need to be carried out to explore the extensive therapeutic values of Glycyrrhiza glabra Linn.

\section{References}

1. Pravin CT., Medicinal plants Utilisation and Conservation $2^{\text {nd }}$ Revised and Enlarged Edition, Aavishkar Publishers, Distributors Jaipur, 2009: 413-414

2. Fatima KK., James ST., Effect of gamma irradiation on the antimicrobial and free radical scavenging activities of Glycyrrhiza glabra root, Radiation Physics and Chemistry,2010; 79: 507-512

3. Ghani HN., Khaza Inul Advia. Idara Kitab-Ul-Shifa, New Delhi 2, YNM: $1260-1261$

4. Kabiruddin H. Makhzanul Mufradat . faisal, Deoband Saharnpur.YNM: 549-551 
5. Bahmani M., Kopaei MR., Jeloudari M., Eftekhari Z., Delfan B., Zargaran A., Forouzan S., A review of the health effects and uses of drugs of plant licorice (Glycyrrhiza glabra L.) in Ira., Asian Pac J Trop Dis 2014; 4(Suppl. 2): S847-S849

6. Pullaiah T., Encyclopadaedia of World Medicinal Plants, Regency Publications New Delhi 08,2006; 2: 1019-21

7. Ali M., Text book of pharmacognosy. CBS Publishers and Distributer, YNM: 119-121

8. Anonymous. The Unani Pharmacopoeia of India: Ministry of Health \& family Welfare, Dept. of AYUSH, New Delhi, 2007; I(I): 9-10

9. Khare C.P., Indian Medicinal Plants An Illustrated Dictionary, Springer, 2007: 289-290

10. Nadkarni KM. Indian Materia Medica, Vol-I, Popular Prakashan, Mumbai, 1976: 582-584

11. Kokate CK., Purohit AP., Gokhale SB., Pharmacognosy: Nirmali Parkashan, J M Road, Pune, 54 ${ }^{\text {th }}$ Ed, pp. 9.64-9.68

12. The wealth of India. A dictionary of Indian, Raw materials and industrial products vol, VII:NPe, CSIR 2009:151-54

13. Ansari H., Essential of Pharmacognosy, Birla Publication Pvt. Ltd. Shahadra Delhi 32, 2013: 190-194

14. Al-Snafi AE., Glycyrrhiza glabra: A phytochemical and pharmacological review, IOSR Journal Of Pharmacy,2018; 8(6)I: 01-17

15. Khan MA. Muhīt-i A'zam, Central Council for Research in Unani Medicine, Ministry of AYUSH, Govt. of India, New Delhi, 110058, 2012; I: 342-344

16. Kirtikar K.R. Indian Medicinal Plants with Illustrtion, Pub. Orientar Enterprises, Dehra Dun Utra Khand,2012; 3: 20212023

17. Tarique NA, Tajul Mufradat (Khawasul Advia): Idarah Kitab al-Shifa Kucha Cheelan, Delhi-2, 2010; 693-695

18. Khan JA., Nikhat S., Mufradat-e-Maseehai. Masood publishing house Deoband, 2012; 6

19. Kabīruddin MH. Tarjama Nafisi fann-e-Sani Ilmul Advia, Advia Mufrada, YNM; 341-342

20. Chakravarthi KK , Avadhani R and Narayan RS . Effect of Glycyrrhiza glabra root extract on learning and memory in wistar albino rats. Int J Biol Med Res 2012; 3(3): 2059-2064.

21. Chakravarthi KK, Avadhani R and Narayan RS. Effects of Glycyrrhiza glabra root extract on learning and memory in wistar albino rats. Drug Invention Today 2012; 4(7): 387-390.

22. Chakravarthi KK and Avadhani R. Beneficial effect of aqueous root extract of Glycyrrhiza glabra on learning and memory using different behavioral models: An experimental study. J Nat Sci Biol Med 2013; 4(2):420-425.

23. Cui YM, Ao MZ, Li W and Yu LJ. Effect of glabridin from Glycyrrhiza glabra on learning and memory in mice. Planta Med 2008;74(4):377-380.

24. Teltumbde AK, Wahurwagh AK, Lonare MK and Nesari TM. Effect of Yashtimadhu (Glycyrrhiza glabra) on intelligence and memory function in male adolescents. Sch J App Med Sci 2013; 1(2):90-95.

25. Zhu Z, Li C, Wang X, Yang Z, Chen J, Hu L, Jiang H and Shen X. $2,2^{\prime}, 4^{\prime}$-Trihydroxychalcone from Glycyrrhiza glabra as a new specific BACE1 inhibitor efficiently ameliorates memory impairment in mice. J Neurochem 2010; 114: 374-385.

26. Al-Jawad FH, Al-Razzuqi RAM, Hashim HM and Al-Bayati NJM. Glycyrrhiza glabra versus Boswellia carterii in chronic bronchial asthma: A comparative study of efficacy. Indian Journal of Allergy, Asthma and Immunology 2012; 26(1): 6-8.

27. Davis EA and Morris DJ. Medicinal uses of licorice through the millennia: the good and plenty of it. Molecular and Cellular Endocrinology 1991; 78: 1-6.

28. Glycyrrhiza glabra. Monograph. Alternative Medicine Review 2005; 10: 230-237.

29. Hikino H. Recent research on oriental medicinal plants, In: Economic and medicinal plant research, $\mathrm{H}$ Wagner, $\mathrm{H}$ Hikino, NR Farnsworth (Eds), London, Academic Press, 1985; 1: 5385.

30. Dhingra D and Sharma A. Antidepressant-like activity of Glycyrrhiza glabra L in mouse models of immobility tests. Progress in Neuro-Psychopharmacology and Biological Psychiatry 2006; 30(3): 449-454.

31. Nirmala $P$ and Selvaraj T. Anti-inflammatory and antibacterial activities of Glycyrrhiza glabra L. Journal of Agricultural Technology 2011; . 7(3): 815-823.
32. .Kaur P, Kaur S, Kumar S and Singh P. Rubia cordifolia L and Glycyrrhiza glabra L medicinal plants as potential source of COX-2 inhibitors. Am J Biomed Sci 2010; 2(2): 108-120.

33. Okimasu E, Moromizato $\mathrm{Y}$, Watanabe $\mathrm{S}$, et al. Inhibition of phospholipase A2 and platelet aggregation by glycyrrhizin, an antiinflammation drug. Acta Med Okayama 1983; 37:385-391

34. Ohuchi $\mathrm{K}$ and Tsurufuji A. A study of the anti-inflammatory mechanism of glycyrrhizin. Mino Med Rev 1982; 27:188-193.

35. Rodino S, Butu A, Butu M and Cornea PC. Comparative studies on antibacterial activity of licorice, elderberry and dandelion. Digest Journal of Nanomaterials and Biostructures 2015; 10(3): 947-955.

36. Sultana S, Haque A, Hamid K, Urmi KF and Roy S Antimicrobial, cytotoxic and antioxidant activity of methanolic extract of Glycyrrhiza glabra. Agric Biol J N Am 2010; 1(5): 957-960

37. Vivek K. Gupta , Atiya Fatima , Uzma Faridi , Arvind S. Negi, Karuna Shanker, J.K. Kumar, Neha Rahuja, Suaib Luqman, Brijesh S. Sisodia, Dharmendra Saikia, M.P. Darokar, Suman P.S. Khanuja, Antimicrobial potential of Glycyrrhiza glabra roots, Journal of Ethnopharmacology 116 (2008) 377-380

38. Abbas A, Zubair M, Rasool N and Rizwan K. Antimicrobial potential of Glycyrrhiza glabra. Journal of Drug Design and Medicinal Chemistry 2015; 1(2): 17-20.

39. Mori K, Sakai H, Suzuki S, Sugai K, Akutsu Y, Ishikawa M, Seino Y, Ishida N, Uchida T, Kariyone S et al. Effects of glycyrrhizin (SNMC: Stronger neo minophagenin hemophilia patients with HIV-1 infection. Tohoku J Exp Med 1989; 158(1):25-35.

40. Badr SEA, Sakr DM, Mahfouz SA and Abdelfattah MS. Licorice (Glycyrrhiza glabra L.): Chemical composition and biological impacts. Research Journal of Pharmaceutical, Biological and Chemical Sciences 2013; 4(3): 606-621.

41. Chin YW, Jung HA, Liu Y, Su BN, Castoro JA, Keller WJ,. Pereira MA and Kinghorn AD. Anti-oxidant constituents of the roots and stolons of licorice (Glycyrrhiza glabra). J Agric Food Chem 2007; 55 (12): 4691-4697

42. Al-Obaidi OHS. Aqueous and alcoholic extracts from Glycyrrhiza glabra and their activity against bacteria and rhabdomyo sarcoma. Eur Chem Bull 2014; 3(2): 133-137.

43. Nagaraj SRM, Lingaraj SM, Balaraju Y, Kumar A and Salimath BP. MTA1 induced angiogenesis, migration and tumor growth is inhibited by Glycyrrhiza glabra. IOSR Journal of Pharmacy 2013; 2(4): 34-43.

44. Adel M, Alousi LA and Salem HA. Licorice: A possible antiinflammatory and anti-ulcer drug. AAPS Pharm Sci Tech 2005; 6: 74-82.

45. Horwich L and Galloway R. Treatment of gastric ulceration with carbenoxolone sodium: clinical and radiological evaluation. Br Med J 1965; 2: 1274-1277.

46. Fraser PM, Doll R, Langman MJ, Misiewicz JJ and Shawdon HH. Clinical trial of a new carbenoxolone analogue (BX24), zinc sulphate, and vitamin A in the treatment of gastric ulcer. Gut 1972; 13: 459-463.

47. Montgomery RD, Lawrence IH, Manton DJ, Mendl K and Rowe P. A controlled trial of carbenoxolone sodium capsules in the treatment of duodenal ulcer. Gut 1968, 9: 704-706.

48. Doll R, Langman MJS and Shawdon HH. Treatment of gastric ulcer with carbenoxolone: antagonistic effect of spironolactone. Gut 1968; 9: 42-45

49. Tewari SN and Wilson AK. Deglycyrrhizinated liquorice in duodenal ulcer. Practitioner 1973; 210:820-823.

50. Kassir ZA. Endoscopic controlled trial of four drug regimens in the treatment of chronic duodenal ulceration. Ir Med J 1985; 78:153-156

51. Krausse R, Bielenberg J, Blaschek W and Ullmann U. In vitro anti-Helicobacter pylori activity of extractum liquiritiae, glycyrrhizin and its metabolites. Journal of Antimicrobial Chemotherapy 2004; 54: 243-246.

52. Gharib naseri $M$, Arabiyan $M$ and Gharib naseri $Z$. Antispasmodic effect of hydroalcoholic leaf extract of licorice ileum contraction in rat. Shahrekord Journal of Medical Sciences 2008; 9: 1-9

53. Ghayedi N, Khoshnam SE and Bahaoddini A. The effect of hydro-alcoholic extract of licorice (Glycyrrhiza glabra) rhizome on the mechanical activity of the colon of male rats and its interaction with adrenergic system. Armaghane Danesh 2016; 21 (3): 225-237. 
54. .Chen G, Zhu L, Liu Y, Zhou Q, Chen $H$ and Yang J. Isoliquiritigenin, a flavonoid from Licorice, plays a dual role in regulating gastrointestinal motility in vitro and in vivo. Phytother Res 2009; 23: 498-506.

55. Sato Y, He J X, Nagai H, Tani T, Akao T. Isoliquiritigenin, one of the antispasmodic principles of Glycyrrhiza ularensis roots, acts in the lower part of intestine. Biol Pharm Bull 2007, 30: 145-149

56. Khoshnazar SM, Bahaoddini A and Najafipour H. Effect of alcoholic extract of licorice (Glycyrrhiza glabra L.) rhizome on isolated duodenum motility in male rats and its interference with cholinergic, nitrergic, and adrenergic systems. Bull Env Pharmacol Life Sci 2013; 2 (12):173-177

57. Takii H, Kometani T, Nishimura T, Nakae T, Okada S and Fushiki T. Antidiabetic effect of glycyrrhizin in genetically diabetic KK-Ay mice. Biol Pharm Bull 2001;24(5):484-487.

58. Sen S, Roy M and Chakraborti AS. Ameliorative effects of glycyrrhizin on streptozotocin-induced diabetes in rats. J Pharm Pharmacol 2011; 63(2): 287-296.

59. Maurya SK, Raj K and SrivastavaAK. Antidyslipidaemic activity of Glycyrrhiza glabra in high fructose diet induced dsyslipidaemic Syrian golden hamsters. Indian J Clin Biochem 2009; 24(4): 404-409.

60. Dushkin M, Khrapova M, Kovshik G, Chasovskikh M, Menshchikova E, Trufakin V, Shurlygina A and Vereschagin E. Effects of Rhaponticum carthamoides versus Glycyrrhiza glabra and Punica granatum extracts on metabolic syndrome signs in rats. BMC Complement Altern Med 2014;14:33

61. Awate SA, Patil RB, Ghode PD, Patole V, Pachauri D and Sherief SH. Aphrodisiac activity of aqueous extract of Glycyrrhiza glabra in male wistar rats. WJPR 2012; 1: 371-378

62. Armanini D, Castello R, Scaroni C et al. Treatment of polycystic ovary syndrome with spironolactone plus licorice. Eur J Obstet Gynecol Reprod Biol 2007; 131(1): 61-67.
63. Armanini D, Fiore C, Mattarello MJ, Bielenberg J and Palermo M. History of the endocrine effects of licorice. Exp Clin Endocrinol Diabetes 2002; 110: 257-261

64. Davis E.A., Morris DJ., Medicinal uses of licorice through the millennia: the good and plenty of it, Molecular and Cellular Endocrinology, 1991; 78: P.1-6

65. Shihata IM and Elghamry MI. Estrogenic activity of Glycyrrhiza glabra with its effect upon uterine motility at various stages of sex cycle . Zentralblatt für Veterin Medizin Reihe 1963; 10(2): 155-162.

66. Karahan F, Avsar C, Ozyigit II and Berber I. Antimicrobial and antioxidant activities of medicinal plant Glycyrrhiza glabra var. glandulifera from different habitats. Biotechnology \& Biotechnological Equipment 2016; 30:4: 797-804.

67. Chopra PKPG, Saraf BD, Inam F and Deo SS. Antimicrobial and antioxidant activities of methanol extract roots of Glycyrrhiza glabra and HPLC analysis. Int J Pharm Pharmacol Sci 2013;5:157-160

68. Vikhe GP, Vikhe PP, Naik SS, Gavhane AJ and Gaikar RB. In vitro effect of G. glabra and T. Cordifolia plant extracts on phagocytosis by human neutrophils.Pravara Medical Review 2013; 5(22):12-15.

69. Moradi N, Ghazi S, Amjadian T, Khamisabadi H and Habibian M. Performance and some immunological parameter responses of broiler chickens to licorice (Glycyrrhiza glabra) extract administration in the drinking water. Annual Research \& Review in Biology 2014; 4(4): 675-683

70. Asl MN., Hosseinzadeh H., Review of Pharmacological Effects of Glycyrrhiza sp. and its Bioactive Compounds, phytotherapy research Phytother. Res., 2008; 22: 709-724

71. Kaur R., Kaur H., Dhindsa AS., Glycyrrhiza glabra: a phytopharmacological review, IJPSR, 2013; 4(7): 2470-2477 